Jurnal Abdidas Volume 1 Nomor 4 Tahun 2020 Halaman 242 - 247

JURNAL ABDIDAS

Community Development Service on Educational and Health Sciences

http://abdidas.org/index.php/abdidas

\title{
Kuliah Kerja Nyata COVID-19 sebagai Agen Informasi Pencegahan Penyebaran COVID-19 di Masyarakat
}

\author{
Tiyas Nur Haryani' ${ }^{1}$, Bima Maulana Rahmad Hidayat ${ }^{2}$ \\ Program Studi Ilmu Administrasi Negara Fakultas Ilmu Sosial dan Politik Universitas Sebelas Maret ${ }^{1,2}$ \\ E-mail : tiyasnur@gmail.com ${ }^{1}$ bimamaulana81@gmail.com ${ }^{2}$
}

\begin{abstract}
Abstrak
Di Indonesia situasi kasus COVID-19 belum menunjukkan grafik yang melandai. COVID-19 merupakan virus baru yang muncul di tahun 2020 sehingga masih dalam tahap pengembangan vaksinnya dan dalam aspek tingkat pengetahuan mengenai virus baru ini masih terus dilakukan penelitian. Pengetahuan masyarakat tentang virus dan pandemi COVID-19 juga belum seutuhnya, maka dukungan pemahaman mengenai virus dan pandemi ini perlu terus dilakukan oleh stakeholders. Perguruan tinggi perlu terlibat dan hadir di masyarakat dalam kegiatan pengabdian kepada masyarakat. Kuliah Kerja Nyata adalah salah satu bentuk pengabdian perguruan tinggi pada masyarakat. Di masa pandemi COVID-19 KKN tetap berjalan secara daring dan physical distancing. Kegiatan KKN COVID-19 dalam pembahasan ini dilakukan di Mandungan RT 003 RW 010 Desa Trangsan Kecamatan Gatak Kabupaten Sukoharjo. Lokasi pengabdian merupakan lokasi lingkungan tinggal anggota tim pengabdian. Kegiatan dilakukan dengan pendidikan masyarakat berupa sosialisasi seputar COVID19 dan pelatihan cuci tangan. Dalam durasi satu bulan pendidikan masyarakat berlangsung daring melalui whatsapp group dan instagram. Hasilnya masyarakat setempat antusias dalam menambah wawasan seputar COVID-19 dan diharapkan bekal pengetahuan dapat mencegah penyebaran pandemi COVID-19 di lokasi KKN.
\end{abstract}

Kata kunci: COVID-19, informasi, kuliah kerja nyata, pencegahan

\begin{abstract}
In Indonesia, the situation of the COVID-19 case has not shown a sloping graph. COVID-19 is a new virus that will emerge in 2020, so it is still in the development stage of its vaccine and in terms of the level of knowledge about this new virus, research is still being carried out. Public knowledge about the COVID-19 virus and pandemic is also incomplete, so stakeholders need to continue to support understanding of the COVID-19 virus and pandemic. Higher education institutions need to be involved and present in the community in community service activities. Work Lecture (KKN) is one form of higher education service to society. During the COVID19 pandemic, KKN continued to online and physically distancing. KKN COVID-19 was carried out at Mandungan RT 003 RW 010 Trangsan Village, Gatak District, Sukoharjo Regency. Activities carried out with community education in the form of socialization about Covid-19 and hand washing training. Within one month of community education takes place online via WhatsApp group and Instagram. As a result, the local community is enthusiastic in adding insight about COVID-19 and it is hoped that knowledge can prevent the spread of the COVID-19 pandemic at KKN locations.
\end{abstract}

Keywords: COVID-19, information, community service program, prevention

Copyright (c) 2020 Tiyas Nur Haryani, Bima Maulana Rahmad Hidayat

$\triangle$ Corresponding author
Address : Universitas Sebelas Maret
Email : tiyasnur@gmail.com
Phone $: 082322494219$

ISSN 2721- 9224 (Media Cetak)

ISSN 2721- 9216 (Media Online)

DOI: https://doi.org/10.31004/abdidas.v1i4.52 


\section{PENDAHULUAN}

Semenjak World Health Organization (WHO) mengumumkan COVID-19 berstatus pandemi internasional pada 11 Maret 2020, kewaspadaan, kesiapsiagaan, pencegahan dan penanganan pun masif digencarkan di berbagai negara. Terus meningkatnya angka kasus masyarakat dunia yang terpapar COVID-19 dan pasien meninggal karena COVID-19 beserta faktor komorbidnya membuat WHO bergerak cepat dan responsif serta mengarahkan dan menghimbau seluruh negara di dunia untuk menyusun kebijakan publik dan kampanye pengarusutamaan protokol kesehatan bagi warga negaranya. Indonesia pada 2 Maret 2020 melalui Presiden Joko Widodo didampingi Menteri Kesehatan, dr. Terawan mengumumkan dua kasus pertama WNI yang positif COVID-19.

Semenjak laporan tersebut, berbagai upaya ditempuh pemerintah untuk menangani penyebaran pandemi dan melakukan kampanye pencegahan untuk memutus mata rantai COVID19. Sampai dengan tulisan ini dituliskan (Juli, 2020) jumlah positif COVID-19 di Indonesia masih mengalami eksponensial kenaikan. Mengutip data dari website resmi Covid19.co.id, hingga sekarang ini per 13 Juli 2020 jumlah positif COVID-19 di Indonesia meningkat signifikan mencapai 76.981 dengan pasien sembuh 36.689 dan meninggal dunia 3.656 (G. T. P. P. COVID19, 2020).

Pada beberapa sebaran kasus pandemi COVID-19 di Indonesia, Provinsi Jawa Tengah yang masih berada zona merah dan telah ditetapkan sebagai Kejadian Luar Biasa (KLB) bahkan terdapat kasus positif terbanyak seKaresidenan Surakarta yakni Kabupaten Sukoharjo. Berdasarkan data yang bersumber dari corona.sukoharjo.go.id, per 13 Juli 2020, 119 pasien positif COVID-19 dengan rincian sembuh orang dan meninggal 5 orang, 27 PDP, 738 ODP dan 882 OTG di Kabupaten Sukoharjo (S. T. COVID-19, 2020). Hal ini perlu dilakukan pengarusutamaan protokol kesehatan dan kampanye pencegahan penyebaran COVID-19 oleh stakeholders. Hal tersebut dapat menggiatkan pemahaman masyarakat terkait pencegahan dan penanganan COVID-19 agar harapan untuk memutus penularan dan tidak ada penambahan pasien COVID-19 dapat terealisasikan dengan baik. Salah satu kecamatan yang berada di Kabupaten Sukoharo yang sudah terkonfirmasi positif COVID-19 atau sudah dalam kawasan kecamatan zona merah adalah Kecamatan Gatak. Data dari corona.sukoharjo.go.id menyatakan per 13 Juli 2020 Kecamatan Gatak 2 positif COVID19, 4 PDP dan 19 ODP (S. T. COVID-19, 2020). Oleh karena itu sangat penting dan perlu dilakukan upaya yang masif tentang pencegahan COVID-19 sekaligus tidak menambah jumlah yang terkonfirmasi positif COVID-19 oleh masyarakat di Kecamatan Gatak sebagai kawasan zona merah di Sukoharjo.

Perguruan tinggi harus hadir di masyarakat lewat kegiatan pengabdian kepada masyarakat. Tim perguruan tinggi yang tengah bertugas dalam program Kuliah Kerja Nyata COVID-19 Universitas Sebelas Maret mencoba hadir di tengah-tengah masyarakat dalam upaya penanggulangan pandemi COVID-19. Kuliah 
Kerja Nyata COVID-19 Universitas Sebelas Maret melakukan upaya tanggap wabah COVID-19 di Mandungan RT 003 RW 010 Desa Trangsan Kecamatan Gatak Kabupaten Sukoharjo, sebagai lokasi terdekat tim pengabdian. Desa Trangsan sendiri tercatat kasus ODP sejumlah 3 orang per 13 Juli 2020 (S. T. COVID-19, 2020). Maka dari itu sangat perlu dilakukan supporting pemahaman masyarakat tentang COVID-19 sebagai upaya pencegahan penyebaran pandemi COVID-19. Tim pengabdian berharap melalui Program KKN ini mampu menggugah masyarakat Dukuh Mandungan RT 003 RW 010 untuk terus melaksanakan protokol kesehatan secara kolektif saling mengedukasi baik secara informatif, fisik, mental dan spiritual sehingga mampu melewati bencana pandemi ini.

\section{METODE}

Kuliah Kerja Nyata COVID-19 ini dilakukan dengan pendekatan pendidikan masyarakat dan pelatihan praktik pencegahan penyebaran virus COVID-19. Dengan sasaran kelompok penerima manfaat adalah masyarakat sekitar tempat tinggal tim pengabdian yakni Mandungan RT 003 RW 010 Desa Trangsan. Langkah tersebut diambil sebab adanya kebijakan physical distancing dari pemerinah sebagai upaya pencegahan penularan virus COVID-19 di masyarakat. Kebijakan physical distancing juga membuat pelaksanaan kegiatan banyak berjalan secara daring menggunakan Teknologi Komunikasi dan Informasi khususnya melalui sosial media dan media dark social. Kegiatan pengabdian dengan pemanfaatan media daring menjadi alternatif pendampingan yang dapat dilakukan di masa pendemi COVID-19 (Wardhani, 2020). Hasil pengabdian sebelumnyanya menunjukkan pendampingan virtual masih bisa efektif (Ismail, 2020).

Kegiatan dilakukan dengan langkah awal berupa perencanaan. Di dalam perencanaan dilakukan analisis situasi untuk membantu membangun kebutuhan dan metode pendampingan yang selanjutnya seletah perencanaan kegiatan dilaksanakan sesuai dengan perencanaan jadwal kegiatan (Haryani, 2020). Pendidikan masyarakat dilakukan melalui sosialisasi mengenai informasi pencegahan penularan virus COVID-19. Sosialiasi dilakukan secara rutin dan berkala melalui daring di media sosial instagram dan media dark social whatsapp group warga Mandungan RT 003 RW 010 Desa Trangsan. Pelatihan dilakukan langsung kepada kelompok anak-anak dengan materi praktik cuci tangan yang benar dengan air dan sabun. Kegiatan pelatihan cuci tangan dilakukan dua kali selama program Kuliah Kerja Nyata COVID 19 berlangsung di Mandungan RT 003 RW 010 Desa Trangsan. Kegiatan seluruhnya berlangsung selama satu bulan.

\section{HASIL DAN PEMBAHASAN}

Sebagai pembukaan Kuliah Kerja Nyata COVID-19 di Mandungan RT 003 RW 010 Desa Trangsan Kecamatan Gatak Kabupaten Sukoharjo tim pengabdian pertama kali melakukan perkenalan kegiatan yang berlangsung selama satu bulan periode Juli-Agustus 2020. Kegiatan pengenalan program dilakukan secara online di whatsapp group kelompok Bapak-bapak, Karang 
Taruna dan Ibu-ibu PKK Mandungan RT 003 RW 010 Desa Trangsan Kecamatan Gatak Kabupaten Sukoharjo. Komunikasi dan sosialiasi daring dilakukan dalam rangka physical distancing, sehingga kegiatan Kuliah Kerja Nyata berlangsung di ruang sosial media kelompok masyarakat dan tidak mengumpulkan warga secara tatap muka dalam jumlah besar.

Kegiatan yang selanjutnya dilaksanakan secara daring adalah pendidikan masyarakat Program Pemahaman Dasar COVID-19. Terdapat empat program kerja secara daring dengan membagikan poster online. Pertama, Program Pemahaman Dasar COVID-19 yang memuat empat kali kegiatan yakni:

1) pengenalan virus COVID-19,

2) sosialisasi pemahaman proses penularan COVID-19 (droplet, kontak erat, menyentuh benda terkontaminasi);

3) sosialisasi Pemahaman kelompok rentan terserang COVID-19; dan

4) sosialisasi Pemahaman tanda dan gejala COVID-19

Kedua, program pemahaman cara dan perilaku pencegahan COVID-19 yang terdiri kegiatan pelatihan cuci tangan pakai sabun dengan benar yang menyasar kelompok anak-anak di Mandungan RT 003 RW 010 Desa Trangsan.

Kegiatan daring berlangsung dalam 4 kali frekuensi dengan rincian sebagai berikut :

\section{Frekuensi ke 1 sosialisasi Pengenalan Virus COVID-19}

a. Tanggal 24 Juli 2020 membagikan poster ke whatsapp group Karang Taruna
Mandungan RT 003 RW 010 Desa Trangsan dengan hasil pembaca berjumlah 47 orang dan sebagian memberikan respon terhadap kiriman poster tersebut.

b. Tanggal 25 Juli 2020 membagikan poster ke whatsapp group RT kelompok BapakBapak Mandungan RT 003 RW 010 Desa Trangsan dengan hasil pembaca berjumlah 42 orang dan sebagian memberikan respon terhadap kiriman poster tersebut.

c. Tanggal 25 Juli 2020 membagikan poster ke whatsapp group kelompok Ibu-Ibu Mandungan RT 003 RW 010 Desa Trangsan dengan hasil pembaca berjumlah 43 orang dan sebagian memberikan respon terhadap kiriman poster tersebut.

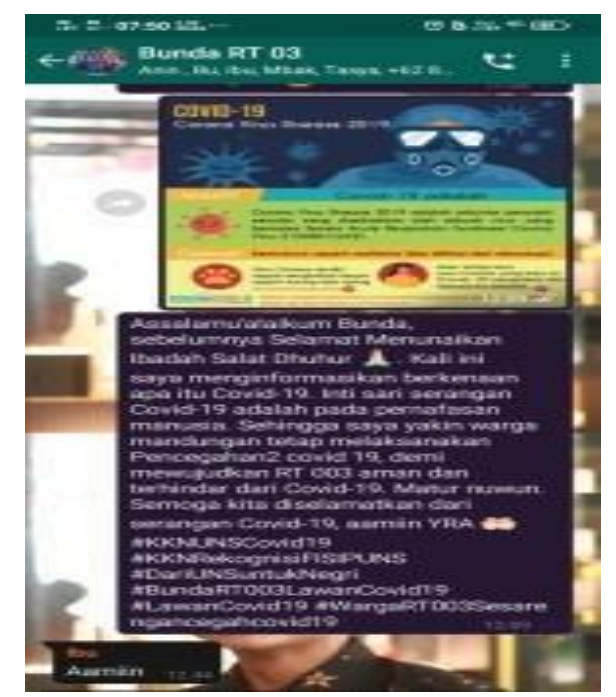

Gambar 1 Share Poster Sosialisasi Informasi Virus COVID-19 via Whatsapp Group

\section{Frekuensi ke 2 Sosialisasi Pemahaman Tanda dan Gejala COVID-19}

a. Tanggal 27 Juli membagikan poster ke whatsapp group Karang Taruna Mandungan 
RT 003 RW 010 Desa Trangsan dengan hasil pembaca berjumlah 46 orang dan sebagian memberikan respon terhadap kiriman poster tersebut.

b. Tanggal 27 Juli 2020 membagikan whatsapp group RT kelompok Bapak-Bapak Mandungan RT 003 RW 010 Desa Trangsan dengan hasil pembaca berjumlah 42 orang dan sebagian memberikan respon terhadap kiriman poster tersebut.

c. Tanggal 27 Juli 2020 membagikan poster ke whatsapp group kelompok Ibu-Ibu Mandungan RT 003 RW 010 Desa Trangsan dengan hasil pembaca berjumlah 43 orang dan sebagian memberikan respon terhadap kiriman poster tersebut.

\section{Frekuensi ke 3 Sosialisasi Pemahaman} Proses Penularan COVID-19

a. Tanggal 27 Juli 2020 membagikan poster ke whatsapp group kelompok Ibu-Ibu Mandungan RT 003 RW 010 Desa Trangsan dengan hasil pembaca berjumlah 43 orang dan sebagian memberikan respon terhadap kiriman poster tersebut.

b. Tanggal 29 Juli 2020 membagikan poster ke whatsapp group Karang Taruna Mandungan RT 003 RW 010 Desa Trangsan dengan hasil pembaca berjumlah 45 orang dan sebagian memberikan respon terhadap kiriman poster tersebut.

c. Tanggal 27 Juli 2020 membagikan whatsapp group RT kelompok Bapak-Bapak Mandungan RT 003 RW 010 Desa Trangsan dengan hasil pembaca berjumlah 42 orang dan sebagian memberikan respon terhadap kiriman poster tersebut.

\section{Frekuensi ke 4 Sosialisasi Pemahaman Kelompok Rentan Terinfeksi COVID-19}

a. Tanggal 1 Agustus whatsapp group RT kelompok Bapak-Bapak Mandungan RT 003 RW 010 Desa Trangsan dengan hasil pembaca berjumlah 39 orang dan sebagian memberikan respon terhadap kiriman poster tersebut.

b. Tanggal 1 Agustus 2020 membagikan poster ke whatsapp group Karang Taruna Mandungan RT 003 RW 010 Desa Trangsan dengan hasil pembaca berjumlah 42 orang dan sebagian memberikan respon terhadap kiriman poster tersebut pernyataan dan pertanyaan.

c. Tanggal 1 Agustus 2020 membagikan poster ke whatsapp group kelompok Ibu-Ibu Mandungan RT 003 RW 010 Desa Trangsan dengan hasil pembaca berjumlah 43 orang dan sebagian memberikan respon terhadap kiriman poster tersebut.

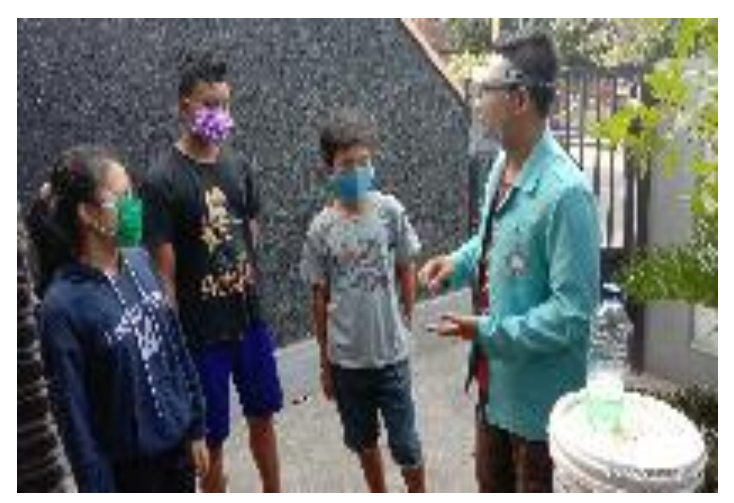

Gambar 2 Pelatihan Praktik Cuci Tangan Kepada Anak-Anak Mandungan RT 003 RW 010 Desa Trangsan 


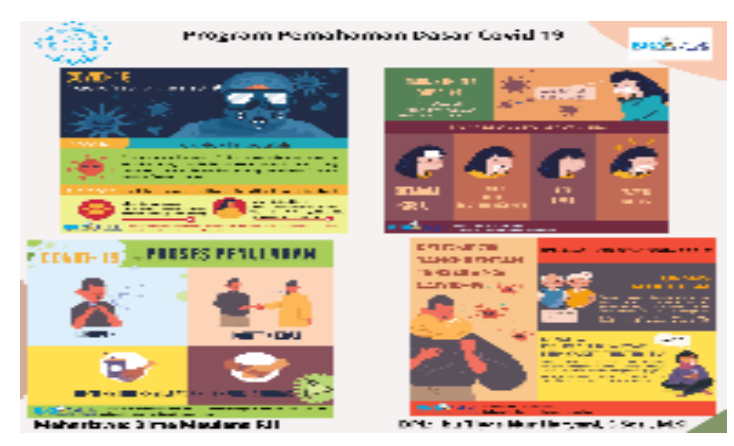

Gambar 3 Materi Poster Sosialisasi Informasi Pencegahan Penyebaran COVID-19

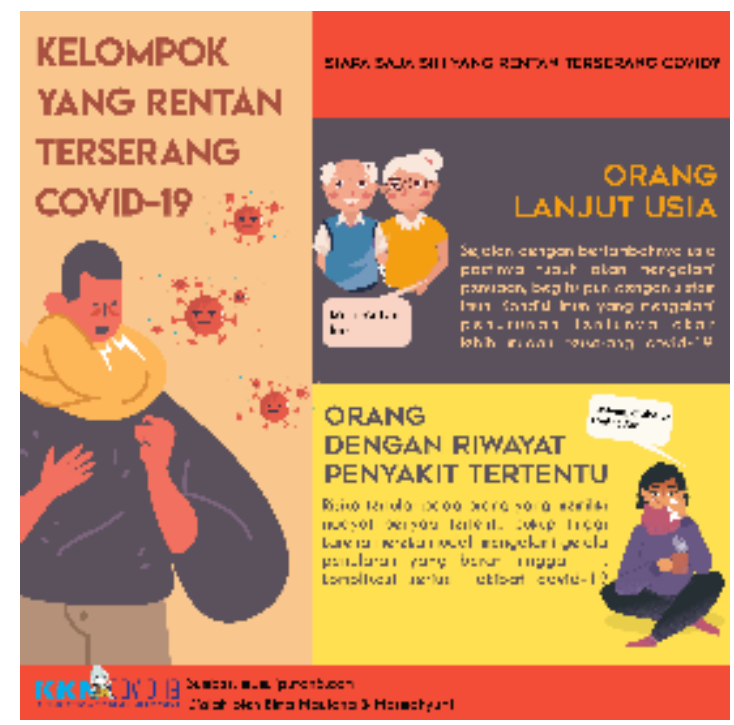

Gambar 4 Materi Poster Sosialisasi Informasi Pencegahan Penyebaran COVID-19

\section{SIMPULAN}

Dari keempat kegiatan tersebut 133 total anggota ketiga whatsapp group cukup antusias dengan paparan poster yang dikirim. Terbukti anggota whatsapp group mayoritas sudah membaca, sebagian memberikan respon positif bahkan ada beberapa pertanyaan. Melalui kegiatan KKN COVID-19 yang menyediakan informasi atau sebagai agen informasi pencegahan penyebaran COVID-19 bagi warga Mandungan RT 003 diharapkan semakin meningkatkan pengetahuan akan bahaya COVID-19 sehingga berimplikasi pada kesadaran tindakan pencegahan penularan COVID-19. Outcome Kuliah Kerja Nyata COVID-19 ini adalah dalam rangka mewujudkan Mandungan RT 003 aman dan terhindar dari COVID-19 mengingat lokasi KKN berada di kecamatan yang berzona merah.

\section{DAFTAR PUSTAKA}

COVID-19, G. T. P. P. (2020). Peta Sebaran. Gugus Tugas Percepatan Penanganan COVID-19. https://covid19.go.id/petasebaran

COVID-19, S. T. (2020). Monitoring Data COVID-19 Kabupaten Sukoharjo. Sukoharjo Tanggap COVID-19. https://corona.sukoharjokab.go.id/

Haryani, T. N. (2020). Pendampingan Kelompok Informasi Masyarakat Desa Sumberdodol Kabupaten Magetan Dalam Pengembangan Iklan Pariwisata Desa. Aptekmas Jurnal Pengabdian Kepada Masyarakat, 3(2).

Ismail, A. et al. (2020). Adaptasi Pendampingan Kesehatan Di Masa Pandemi Covid 19 Studi Strategi Virtual Outreach PKBI Kota Semarang. Jurnal Abdidas, 1(3).

Wardhani, D. K. et al. (2020). Edukasi Pencegahan Penularan COVID - 19 Pada Anak Usia Dini Melalui Media Pembelajaran Audio Visual. Jurnal Abdidas, 1(3). 